\title{
Egg Laying Site and Oviposition Pattern of Two Phthirapteran Species Parasitizing Red Whiskered Bulbul (Pycnonotus jocosus)
}

\author{
Kırmızı Bıyıkı Bülbül’de (Pycnonotus jocosus) Parazitlenen İki Phthirapteran Türünün \\ Yumurtlama Paterni ve Yumurta Bırakma Bölgeleri
}

\author{
Arun Kumar Saxena, Gaurav Arya, Nayanci Bansal \\ Department of Zoology, Government Raza PG College, Rampur, India
}

\section{ABSTRACT}

Objective: Present study was performed to record the oviposition and egg laying pattern of two phthirapteran species infesting red whiskered Bulbul.

Methods: The number of egg laid by each species on different parts of body was recorded by direct observation under stereozoom binocular microscope. Feathers bearing egg were subjected to SEM to observe the pattern of egg laying.

Results: The maximum percentage of egg of the ischnoceran louse, Brueelia guldum were recorded on feather of back region, followed by neck and breast. The amblyceran louse, Menacanthus eurysternus prefers to lay eggs mainly on neck, head and nape feathers.

Conclusion: The ischnoceran louse, Brueelia guldum exhibits widespread oviposition sites while amblyceran louse, Menacanthus eurysternus shows restricted oviposition sites on the host body. (Turkiye Parazitol Derg 2012; 36: 166-8)

Key Words: Oviposition, phthiraptera, lice, amblycera, ischnocera

Received: 31.03.2012

Accepted: 24.07.2012

\section{ÖZET}

Amaç: Bu çalışma kırmızı-bıyıklı Bülbül'ü enfeste eden iki phthirapteran türünün yumurtlama ve yumurta bırakma biçimlerini kaydetmek için yapıldı.

Yöntemler: Her bir tür tarafından vücudun farklı bölgelerine baırakılan yumurta sayısı stereo-zum binoküler mikroskop altında doğrudan gözlem yolu ile kaydedildi. Yumurta taşıyan kuş tüyleri yumurta bırakma biçimini gözlemek için SEM'e tabi tutuldu.

Bulgular: Ischnocera alttakımından bir bit olan Brueelia guldum'un yumurtaları en fazla oranda sırt bölgesi tüylerinde, takiben boyun ve göğüs belgesindeki tüylerde kaydedildi. Amblycera alttakımından bir bit olan Menacanthus eurysternus başlıca boyun, baş ve ense tüylerine yumurta bırakmayı tercih etmekteydi.

Sonuç: Ischnocera alttakımından bir bit olan Brueelia guldum konakçı vücutta yaygın yumurtlama bölgesi göstermekte iken amblycera alttakımından bir bit olan Menacanthus eurysternus kısıtlı yumurtlama bölgesi göstermektedir. (Turkiye Parazitol Derg 2012; 36: 166-8)

Anahtar Sözcükler: Yumurtlama, phthiraptera, bitler, amblycera, ischnocera

Geliş Tarihi: 31.03.2012

Kabul Tarihi: 24.07.2012

Address for Correspondence / Yazışma Adresi: Dr. Arun Kumar Saxena, Department of Zoology, Government Raza PG College, Rampur, India Phone: +919358177162 E-mail: akscsir@rediffmail.com doi:10.5152/tpd.2012.39 


\section{INTRODUCTION}

Phthirapteran ectoparasites exhibit variations with respect to oviposition sites. The oviposition sites and the egg laying pattern of Phthiraptera on selected avian hosts viz. domestic fowl (Gallus gallus domesticus), black bird (Turdus m. merula), mallard duck (Anas platyrhynchos), polygnous peacock (Pavo cristatus), domestic pigeon (Columba livia) and Indian cattle egret (Bubulcus ibis) have been indicated from time to time by certain workers (1-8). In the present report, an attempt has been made to record the egg laying sites and patterns of oviposition of two phthirapteran species (Brueelia guldum and Menacanthus eurysternus) parasitizing red whiskered Bulbul (Pycnonotus jocosus).

\section{METHODS}

The bodies of five infested birds were arbitrarily divided into nine regions (head, neck, nape, breast, abdomen, back, tail, leg and wings) and examined under a stereozoom trinocular microscope (Magnus MSZ-TR), to record the number of eggs of each species in tabular manner. The number of eggs found laid in each region of the bird was summated and divided by the total number of eggs encountered on five birds (to derive clue relating the popular oviposition sites). A few feathers bearing eggs were gently cut from the host body, arranged on aluminum stubs, covered with double sided cellotape, gold coated, and examined under SEM (Mode Leo 435 VP SEM), to record the patterns of oviposition.

\section{RESULTS}

The ischnoceran louse B. guldum showed widespread egg laying sites on the host. The maximum percentage of eggs (79\% of total eggs, $n=5$ ) were found on the feathers from the back region (32\%), followed by neck (26\%) and breast (21\%). Feathers belonging to the abdomen and nape carried $9.0 \%$ and $6.0 \%$ eggs, respectively. A small percentage of eggs were located on the wings and legs (3\% and $2 \%$ ) while a negligible percentage of eggs were noted on the tail region (1\%). However, no eggs were found on the head (Figure 1). All eggs remain glued vertically parallel to the axis of rachis (angle nearly $5^{\circ}-30^{\circ}$ ). The eggs were laid vertically with the postero-lateral end near the rachis in an irregular order (Figure 2A). As many as three eggs have been found on a single feather.

The amblyceran louse $M$. eurysternus exhibited restricted oviposition sites. Seventy three percent of the total eggs $(n=5)$ were found on the feathers from the foreparts of the body (neck, 31\%; head, 25\% and nape, 17\%). The breast appeared to be the next favorite site (11\%). The feathers belonging to the back and abdomen carried $10 \%$ eggs of the aforesaid louse $(6 \%$ and $4 \%$, respectively). A very small percentage of eggs were located on the wings (3\%), legs (2\%) and tail (1\%) (Figure 1). Eggs were found laid on the base of small feathers, close to rachis and remain glued vertically parallel to the axis of the rachis (angle nearly $30^{\circ}-40^{\circ}$ ). Eggs were glued to the rachis through the lateral side and the rear end of the egg remains exposed (Figure 2B). A maximum of four eggs have been found on a single feather.

\section{DISCUSSION}

Some avian lice are known to exhibit protective features with respect to oviposition and prefer to lay eggs in those areas of the body which the host finds comparatively difficult to preen e.g. head and neck region (9). Certain phthirapterans lay their eggs in vulnerable sites and place their elongated eggs between the barbs of the feathers. In general, amblycerans show more site specificity than the ischnoceran species. An amblyceran louse, Actornithophilus patellatus, places its eggs inside the shafts of primary or secondary feathers (9). Different species occurring on the same host often exhibit differences in egg laying sites. For instance, in the case of pigeons, Columbicola columbae and Colpocephalum turbinatum prefer to lay eggs on the wing and tail feathers; Companulotes bidentatus compar

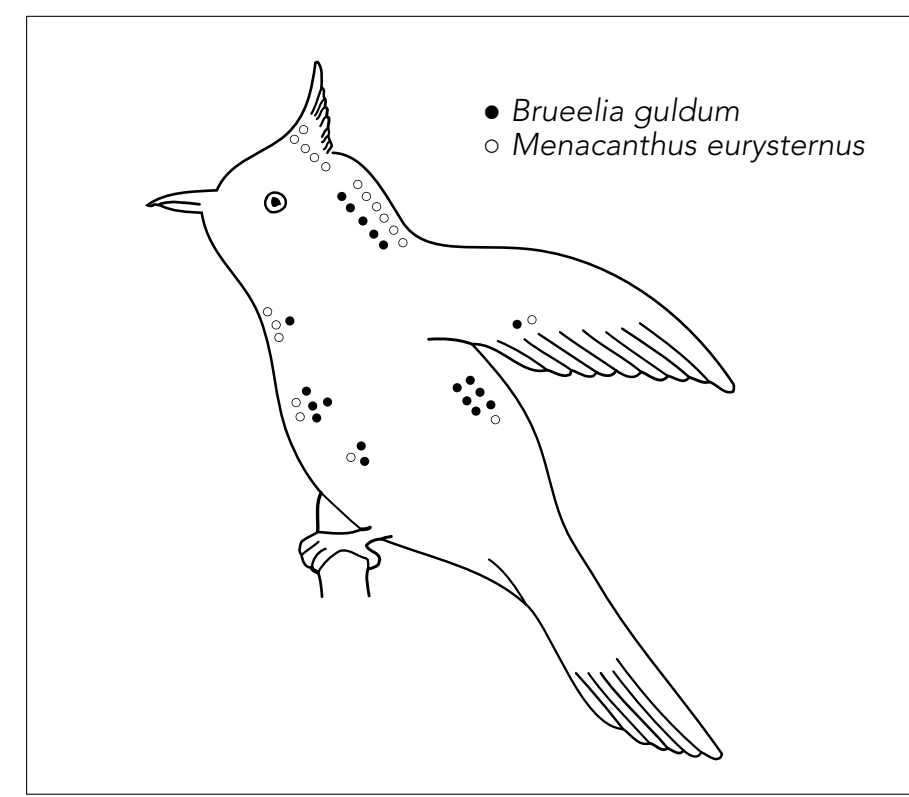

Figure 1. Showing the distribution pattern of the eggs of two types of lice occurring on the red whiskered Bulbul (one $\circ / \bullet=$ $5 \%$ of total eggs)

Table 1. Egg laying sites of ischnoceran louse

\begin{tabular}{|c|c|c|c|}
\hline \multicolumn{4}{|c|}{ B. guldum } \\
\hline Body Parts & \% Egg laid & $\begin{array}{c}\text { Symbol } \\
(\bullet)\end{array}$ & $\begin{array}{c}\text { Loss in round } \\
\text { off }(\bullet)\end{array}$ \\
\hline Head & $\mathrm{Nil}$ & Nil & $\mathrm{Nil}$ \\
\hline Neck & 26 & 5 & $(-1 \%)$ \\
\hline Nape & 06 & 1 & $(-1 \%)$ \\
\hline Breast & 21 & 4 & $(-1 \%)$ \\
\hline Abdomen & 09 & 2 & $(+1 \%)$ \\
\hline Beak & 32 & 6 & $(-2 \%)$ \\
\hline Tail & 01 & $\mathrm{Nil}$ & $(-1 \%)$ \\
\hline Leg & 02 & $\mathrm{Nil}$ & $(-2 \%)$ \\
\hline \multirow[t]{2}{*}{ Wings } & 03 & 1 & $(+2 \%)$ \\
\hline & $100 \%$ & 19 & $\begin{array}{l}-5 \%=1 \bullet \\
(5 \% \text { lost in } \\
\text { round off) }\end{array}$ \\
\hline
\end{tabular}



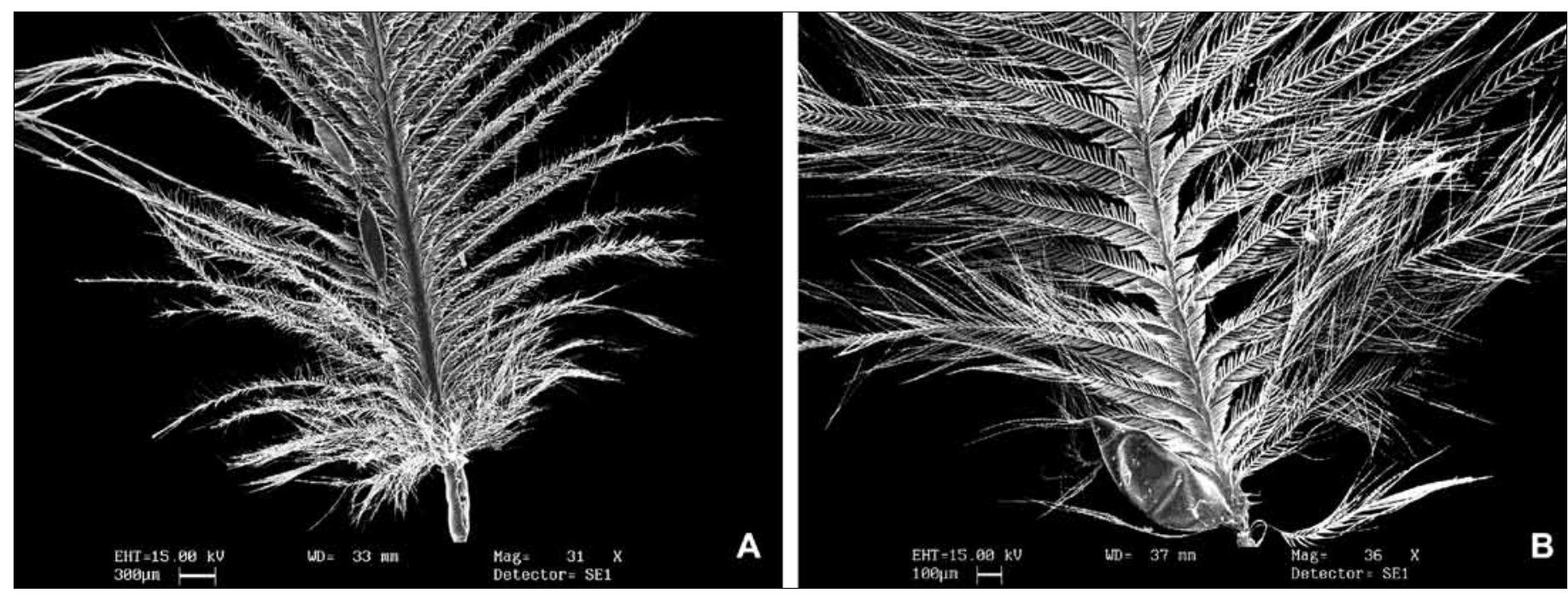

Figure 2. A) SEM photograph showing egg laying pattern of Brueelia guldum on 31x.B) SEM photograph showing egg laying pattern of Menacanthus eurysternus on 36x

Table 2. Egg laying sites of amblyceran louse

\begin{tabular}{|c|c|c|c|}
\hline \multicolumn{4}{|c|}{ M. eurysternus } \\
\hline Body Parts & $\%$ Egg laid & $\begin{array}{l}\text { Symbol } \\
\text { (0) }\end{array}$ & $\begin{array}{l}\text { Loss in round } \\
\text { off (o) }\end{array}$ \\
\hline Head & 25 & 5 & (Nil) \\
\hline Neck & 31 & 6 & $(-1)$ \\
\hline Nape & 17 & 3 & $(-2)$ \\
\hline Breast & 11 & 2 & $(-1)$ \\
\hline Abdomen & 04 & 1 & $(+1)$ \\
\hline Beak & 06 & 1 & $(-1)$ \\
\hline Tail & 01 & Nil & $(-1)$ \\
\hline Leg & 02 & Nil & $(-2)$ \\
\hline \multirow[t]{2}{*}{ Wings } & 03 & 1 & $(+2)$ \\
\hline & $100 \%$ & 19 & $\begin{array}{l}-5 \%=10 \\
(5 \% \text { lost in } \\
\text { round off) }\end{array}$ \\
\hline
\end{tabular}

exhibits widespread oviposition sites and Hohorstiella lata lays the egg on the forepart of the body $(7,10)$. In the case of the red avadavat, Myrsidea amandava oviposite on the breast, back and abdominal region, while Brueelia sp. exhibits widespread oviposition sites, as the eggs are found on feathers belonging to most parts of body (11). The phenomenon of shift in oviposition site (in the case of simultaneous infestation by different species) has been also noted by Nelson (12). In the case of the red whiskered Bulbul, more than $78 \%$ eggs of ischnoceran lice, B. guldum, were present upon feathers of the back, neck and breast region, while the amblyceran, M. eurysternus lays $73 \%$ of its eggs on the forepart of the host body. Thus, like other avian lice, the phthirapterns occurring on the red whiskered Bulbul also exhibit marked differences in the pattern of oviposition.

\section{Acknowledgements}

The authors are indebted to the Principal, Govt. Raza. P.G. College, Rampur (U.P) for providing laboratory facilities; to the
Chief Wild Life Warden of U. P. (India) for permission to catch the birds, and to the CSIR, New Delhi for providing financial support to Dr. A. K. Saxena in the form of project no. 37/ (1298)/07/EMR II.

\section{Conflict of Interest}

No conflict of interest was declared by the authors

\section{REFERENCES}

1. Saxena AK, Singh SK, Surman Kumar A. Site preference of poultry shaft louse, Menopon gallinae (Phthiraptera: Amblycera) on host body. Riv di Parasitol 1997; 14: 383-9.

2. Kumar S, Gupta N, Saxena AK. Egg laying patterns of phthirapteran ectoparasites infesting domestic hen, Gallus gallus domesticus. J Parasit Appl Anim Biol 2006; 15: 11-5.

3. Surman Singh SK. Saxena AK. Kumar A. Aspects of oviposition in the poultry shaft louse Menopon Gallinae (Phthiraptera: Amblycera) Riv di Parasitol 1998; 15: 211-8.

4. Baum H. Biologie und Okologie der Amselfederlouse. Angew Parasitol 1968; 9: 129-75.

5. Strilchuk KW. Distribution of biting lice (Mallophaga) on two wild Mallards (Anas Platyrhynchos). Can Field Nat 1976; 90: 77-8.

6. Stewart IR, Clark F, Petrie M. Distribution of chewing lice upon the polygynous peacock Pavo cristatus. J Parasitol 1996; 82: 370-2. [CrossRef]

7. Singh SK, Kumar A, Badola S, Saxena AK. Site preference of four pigeon lice (Phthiraptera: Insecta) on the host body. Riv di Parasitol 2000; 3: 341-3.

8. Ahmad A, Khan V, Badola S, Arya G, Bansal N, Saxena AK. Population characteristics and the nature of egg shells of two Phthirapteran species parasitizing Indian cattle egrets. J Insect Sci 2010; 10: 163. [CrossRef]

9. Marshall AG. The ecology of ectoparasitic insects. Academic Press, London. 1981

10. Nelson BC, Murray MD. The distribution on Mallophaga on the domestic pigeon (Columba livia). Int J Parasitol 1971; 1: 21-9. [CrossRef]

11. Gupta N, Kumar S, Ahmad A, Saxena AK. Site preference of two phthirapteran ectoparasires on the body of red munia, Estrilda amandava amandava. Res Rev Parasitol. 2005; 65: 67-71.

12. Nelson BC. A revision of the New world species of Ricinus (Mallophaga) occurring on Passeriformes (Aves) Berkley, Los Angeles, London. University of California Press. 1972. 